\title{
PENGARUH TINGKAT SUKU BUNGA DEPOSITO TERHADAP DANA PIHAK KETIGA DI BANK BJB CABANG RANGKASBITUNG
}

\author{
Jamaluddin ${ }^{1)}$ \\ Ahmad Tabrani ${ }^{2)}$ \\ Muksin ${ }^{3)}$ \\ 1) Universitas Islam Negeri SMH Banten \\ ${ }^{2}$ )Universitas Islam Negeri SMH Banten \\ ${ }^{3)}$ Sekolah Tinggi Ilmu Administrasi (STIA) Banten \\ jamaluddin@uinbanten.ac.id
}

\begin{abstract}
The purpose of this study was to determine the effect of deposit interest rates on third party funds in BJB Bank, Branch Rangkasbitung. Data collected is secondary data. Data analysis techniques using simple linear regression. The results indicated that the deposit interest rate had a negative and significant effect on third party funds in BJB Bank Branch Rangkasbitung.
\end{abstract}

Keywords: Deposit interest rates and third party funds

\section{PENDAHULUAN}

Krisis keuangan yang terjadi di berbagai belahan dunia termasuk Indonesia dewasa ini menyadarkan akan pentingnya stabilitas sistem keuangan. Ketidakstabilan sistem keuangan menimbulkan dampak yang sangat buruk yakni menurunnya pertumbuhan ekonomi dan pendapatan serta besarnya biaya pemulihan ekonomi khususnya sektor keuangan akibat krisis tersebut. Dampak dari krisis tersebut maka stabilitas sistem keuangan wajib dipelihara untuk menjamin kepentingan publik. Stabilitas keuangan ini tidak lepas dari peran industri perbankan yang menjadi media penggerak sistem keuangan di Indonesia. Pemulihan industri perbankan yang nyata akan juga berdampak pada sektor lain. Perkembangan dunia bisnis yang terdiri dari beragam perusahaan dan bergerak dalam bidang industri, perdagangan, pertambangan, dan jasa-jasa tak akan lepas dengan masalah kebutuhan dana. Kebutuhan akan dana tersebut ditopang dengan adanya bank yang merupakan lembaga keuangan.

Bank umum (commercial bank) memiliki peranan yang sangat penting dalam menggerakkan roda perekonomian nasional, karena lebih dari 95\% dana pihak ketiga (DPK) perbankan nasional yang meliputi bank umum, bank syariah (sharia bank), dan bank perkreditan rakyat (rural bank) berada di bank umum (Statistik Perbankan Indonesia, diolah). Dana pihak ketiga ini yang selanjutnya digunakan untuk mendorong pertumbuhan ekonomi melalui penyaluran kredit.

Tujuan dari didirikannya suatu perusahaan adalah untuk memperoleh laba. Laba dapat tercapai jika semua sistem dan perangkat dalam perusahaan dapat berjalan sebagaimana mestinya, sesuai dengan apa yang telah ditetapkan oleh perusahaan. Kebijakan yang tepat sasaran, sumber daya manusia yang kompeten serta didukung oleh sarana dan 
prasarana, dan produk-produk yang menarik baik tabungan, deposito, dan Giro.

Menyadari akan semakin ketatnya persaingan perbankan dalam menarik minat nasabah, membuat nasabah mempunyai peluang yang sangat luas untuk mendapatkan produk yang sesuai dengan kebutuhan dan keinginannya. Ini menjadi tantangan tersendiri bagi perbankan, bagaimana menciptakan produk yang sesuai dengan kebutuhan dan keinginan nasabah. Dalam hal ini, pelaku bisnis harus berusaha lebih unggul dari pesaingnya. Selain menyediakan produk yang lebih bermutu, harga yang murah, informasi yang mudah dan layanan yang baik,

Bank adalah lembaga keuangan merupakan salah satu lembaga yang bergerak di bidang jasa. Banyaknya persaingan menjadikan lembaga keuangan berlomba-lomba menjalin hubungan yang baik dengan nasabah dengan tujuan meningkatkan kepercayaan nasabah terhadap lembaga keuangan akan menjadi suatu keuntungan tersendiri, karena dengan demikian loyalitas nasabah akan tumbuh dan tingkat penggunaan jasa lembaga keuangan tersebut semakin tinggi.

Sampai dengan saat ini, Wikipedia menuliskan bahwa jumlah bank yang ada di Indonesia terdiri dari 4 bank BUMN, 55 bank swasta, 26 bank daerah, 12 bank campuran dan 10 bank asing. Dari banyaknya jumlah bank tersebut, tentu saja akan terjadi persaingan dalam merebut pangsa pasar. Setiap bank akan berlomba-lomba untuk mendapatkan nasabah sebanyak-banyaknya. Perlu diketahui juga bahwa dari tujuh bank terbesar di Indonesia dilihat dari sisi penjualan, asset dan laba, dua teratas ditempati oleh BRI dan Bank Mandiri. Dari pemaparan tersebut, PT. Bank Pembangunan Daerah Jawa Barat dan Banten, Tbk. berdiri dengan dilatarbelakangi oleh Peraturan Pemerintah Republik Indonesia nomor 33 tahun 1960 tentang penentuan perusahaan di Indonesia milik Belanda yang dinasionalisasi. Salah satau perusahaan milik Belanda yang berkedudukan di Bandung yang dinasionalisasi yaitu NV Denis (De Erste Nederlandsce Indische Shareholding) yang sebelumnya perusahaan tersebut bergerak di bidang bank hipotek. Sebagai tindak lanjut dari Peraturan Pemerintah nomor 33 tahun 1960 Pemerintah Propinsi Jawa Barat dengan Akta Notaris Noezar nomor 152 tanggal 21 Maret 1961 dan nomor 184 tanggal 13 Mei 1961 dan dibukukan dengan Surat Keputusan Gubernur Propinsi Jawa Barat nomor 7/GKDH/BPD/61 tanggal 20 Mei 1961, mendirikan PD Bank Karya Pembangunan dengan modal dasar untuk pertama kali berasal dari Kas Daerah sebesar Rp 2,500,000 (Dua juta lima ratus ribu rupiah).

Seiring dengan perjalanan waktu, pada tahun 1978, dikeluarkan Peraturan Daerah Propinsi Jawa Barat nomor 11/PD-DPRD/1972 tanggal 27 Juni 1972 tentang kedudukan hukum Bank Karya Pembangunan Daerah Jawa Barat sebagai perusahaan daerah yang menjalankan aktivitas usaha di bidang perbankan. Selanjutnya melalui Peraturan Daerah Propinsi Jawa Barat nomor 1/PD040/PD/1978 tanggal 27 Juni 1978, nama PD Bank Karya Pembangunan Daerah Jawa Barat diubah menjadi Bank Pembangunan Daerah Jawa Barat.

Peningkatan aktivitas usaha terjadi di tahun 1992, yaitu menjadi Bank Umum Devisa berdasarkan Surat Keputusan Direksi Bank Indonesia nomor 25/84/KEP/DIR tanggal 02 November 1992 serta berdasarkan Perda nomor 11 Tahun 1995 mempunyai sebutan "Bank Jabar" dengan logo baru. Perubahan bentuk hukum menjadi Perseroan Terbatas (PT) pada tahun 1999 
dan call name di tahun 2010 melalui Surat Keputusan Direksi nomor 1337/SK/DIR-PPN/2010 tanggal 05 Juli 2010 menjadi bank BJB.

Bank daerah yang mampu bersaing dengan bank nasional di Indonesia ini mempunyai visi untuk menjadi 10 bank terbesar di Indonesia dan berkinerja baik. Sampai dengan saat ini, aset Bank BJB secara konsolidasi lebih dari 70 Triliun dengan modal dasar lebih dari 5 Triliun. Sumber perolehan laba terbesar dari Bank BJB Cabang Rangkasbitung adalah dari sektor kredit kepada pegawai dengan penghasilan tetap termasuk simpanan dana pihak ketiga baik simpanan tabungan, deposito dan giro.

Tingkat suku bunga simpanan yang diberikan kepada nasabah dapat merangsang pihak masyarakat untuk menyimpan uang mereka yang surplus. Lembaga perbankan merupakan salah satu lembaga yang mencari keuntungan. Semakin banyak masyarakat yang mempercayakan uang mereka untuk disimpan oleh pihak bank dengan demikian bank akan mempunyai modal untuk memberikan pinjaman kepada debitur dan mendapatkan keuntungan lebih banyak dari hasil bunga dari pinjaman. Semakin banyaknya bank pesaing di Kabupaten Lebak, khususnya di Rangkasbitung secara tidak langsung mempengaruhi debitur untuk menyimpan dananya di Bank BJB Cabang Rangaksbitung. Dengan demikian, persaingan perbankan khususnya dalam memberikan rate suku bunga kepada debitur, semakin tinggi rate suku bunga yang diberikan kepada debitur akan merangsang debitur untuk menyimpan dananya di Bank BJB Cabang Rangkasbitung.

Tabel 1: Pencapaian Deposito Bank BJB Cabang Rangkasbitung

\begin{tabular}{ccccr}
\hline No & Tahun & $\begin{array}{c}\text { Rate Suku Bunga } \\
(\boldsymbol{\%})\end{array}$ & $\begin{array}{c}\text { DPK (Deposito) } \\
(\mathbf{R p )}\end{array}$ & \multicolumn{1}{c}{ Target (Rp) } \\
\hline 1 & 2015 & 6.50 & 170.380 .611 .231 & 70.477 .000 .000 \\
2 & 2016 & 6.25 & 173.929 .187 .050 & 218.277 .000 .000 \\
3 & 2017 & 5.50 & 167.166 .429 .376 & 189.994 .000 .000 \\
\hline
\end{tabular}

Sumber: Bank BJB Cabang Rangkasbitung (2018)

Berdasarkan tabel 1, pada tahun 2015 dengan suku bunga $6.50 \%$ Bank BJB Cabang Rangkasbitung berhasil membukukan Rp.170,3 milyar dengan targer Rp.70.4 milyar dan semakin meningkat pada tahun 2016, yaitu Rp.173.9 milyar akan tetapi dari segi target tidak tercapai, yaitu Rp.218.2 milyar, dan pada tahun 2017 terjadi penurunan yaitu sebesar Rp.167.1 milyar dikarenakan suku bunga pada tahun 2017 sangat kecil yaitu $5.50 \%$ dan target yang semakin besar, ini mengakibatkan terjadinya penurunan karana debitur mulai beralih ke bank pesaing dengan rate lebih besar.
Masyarakat atau bank sebagai pemilik dana mempunyai suatu keinginan, agar dana yang ada dapat berkembang. Bertambahnya nilai suatu dana merupakan suatu perkembangan yang diinginkan oleh para pemilik dana baik dalam jangka pendek maupun untuk masa yang akan datang. Dalam liberalisasi perbankan telah mencapai beberapa sasaran baik dalam menghimpun sumber-sumber dana, peningkatan efisiensi kerja perbankan maupun dalam peningkatan mekanisme pasar uang yang lebih baik. Penghimpunan dana perbankan yang terdiri dari giro, deposito dan tabungan 
selama periode akhir tahun mengalami peningkatan.

Kebijaksanaan suku bunga yang realitas akan terus dikembangkan dan ini tentunya akan mempengaruhi tinggi rendahnya suku bunga yang ditetapkan sedemikian rupa yang tidak memberatkan bagi usaha pembangunan dan juga tidak memberatkan para nasabah atau para pengusaha. Selain itu kebijaksanaan suku bunga harus mencerminkan langkanya modal yang tersedia dalam perekonomian dan keseluruhan biaya penyaluran modal dari penabung kepada peminjam

Mereka dapat mempercayakan pengelolaan dana tersebut kepada bank dalam bentuk tabungan, deposito maupun giro. Nasabah lebih memilih menginvestasikan kelebihan dananya pada tempat yang memberikan keuntungan yang besar di sertai degan rasa aman akan tetapi masih terdapat nasabah-nasabah yang loyal kepada bank yang masih menempatkan dananya di bank.

Perbankan merupakan salah satu tempat popular menurut UU RI No 10 Tahun 1988 tanggal 10 November 1988 tentang perbankan, dapat disimpulkan bahwa usaha perbankan meliputi tiga kegiatan, yaitu menghimpun dana,menyalurkan dana, dan memberikan jasa bank lainnya

Kegiatan menghimpun dan menyalurkan dana merupakan kegiatan pokok bank sedangkan memberikan jasa bank lainnya hanya kegiatan pendukung. Kegiatan penghimpun dana, berupa mengumpulkan dana dari masyarakat dalam bentuk simpanan giro, tabungan, dan deposito. bank merupakan sarana yang memudahkan aktivitas masyarakat untuk menyimpan uang, dalam hal perniagaan maupun untuk investasi masa depan.

Namun saat ini, dengan semakin maraknya bank bermunculan, temasuk di Rangkasbitung dengan penawaran produk sejenis dengan beberapa keunggulan yang ditawarkan Bank BJB Cabang Rangkasbitung cukup kesulitan dalam meraih nasabah yang potentisal untuk menempatkan dananya di Bank BJB Cabang Rangkasbitung terlebih nasabah menginginkan rate bunga yang lebih besar agar mendapatkan keuntungan dari rate bunga yang tinggi tersebut, akan tetapi bank tidak bisa menaikan suku bunga begitu saja karena terikat oleh peraturan BI No.19/2/PBI/2017 tentang Transaksi Sertifikat Deposito dan BI sebagai acuan bank-bank nasional. Oleh karena itu, perlu dianalisis mengenai pengaruh tingkat suku bunga deposito terhadap dana pihak ketiga di Bank BJB Cabang Rangkasbitung".

\section{METODE PENELITIAN}

Data yang digunakan adalah data sekunder, yaitu data rangkai waktu (time series) suku bunga deposito dan dana pihak ketiga dari tahun 2016 hingga tahun 2018 yang diperoleh dari Bank BJB Cabang Rangkasbitung. Metode analisis data yang digunakan analisis regresi linear sederhana.

\section{HASIL PENELITIAN DAN PEMBAHASAN}

\section{Hasil Penelitian}

$$
\mathrm{Y}=15.55105-1.773909 \mathrm{X}
$$

Berdasarkan hasil penelitian menunjukan bahwa koefisien determinasi $\left(\mathrm{R}^{2}\right)$ sebesar 17,01, artinya kontribusi tingkat suku bunga deposito kepada dana pihak ketiga di Bank BJB Cabang Rangkasbitung sebesar $17,01 \%$ dan sisanya sebesar $82,99 \%$ disumbangkan oleh faktor lain yang tidak diteliti. Hasil uji statistik yang telah dilakukan, terbukti nilai $\rho$-value, yaitu $0.000<0,05$, maka terima $\mathrm{H}_{1}$ artinya cukup bukti untuk 
menyatakan bahwa terdapat pengaruh signifikan tingkat suku bunga deposito terhadap dana pihak ketiga di Bank BJB Cabang Rangkasbitung. Konstanta sebesar 15.55105, artinya jika tingkat suku bunga deposito nilainya adalah 0 , maka besarnya dana pihak ketiga nilainya sebesar - 1.773909. Koefisien regresi tingkat suku bunga deposito sebesar 1.773909, artinya jika setiap peningkatan tingkat suku bunga deposito sebesar 1 satuan, maka akan menurunkan dana pihak ketiga sebesar 1.773909 satuan.

\section{Pembahasan}

Tingkat bunga simpanan yang ditawarkan oleh bank merupakan salah satu daya tarik untuk masyarakat. Dengan adanya penawaran tingkat suku bunga, maka akan mempengaruhi jumlah peningkatan nasabah bank. Semakin banyak jumlah nasabah yang menyimpan dananya akan menambah modal bank untuk disalurkan kembali lewat perkreditan, meski dalam hal ini bank harus mengeluarkan biaya untuk bunga simpanan. Pada tingkat bunga yang lebih tinggi masyarakat akan lebih terdorong untuk mengorbankan atau mengurangi pengeluaran untuk konsumsi guna menambah jumlah tabungannya.

Investasi merupakan fungsi dari tingkat suku bunga. Semakin rendahnya tingkat suku bunga, keinginan untuk melakukan investasi juga tinggi dan sebaliknya, semakin tinggi tingkat suku bunga, akan mempengaruhi rendahnya keinginan masyarakat untuk melakukan investasi, Alasannya adalah seorang pengusaha akan pengeluaran investasi, apabila keuntungan yang diharapkan dari investasi lebih besar dari tingkat suku bunga yang dibayar untuk dana investasi tersebut yang merupakan biaya untuk penggunaan dana (cost of capital).

Dari berbagai jenis simpanan masyarakat baik dalam rupiah maupun valuta asing yang paling besar porsinya adalah komponen deposito. Deposito adalah sejenis jasa tabungan yang biasa ditawarkan oleh bank kepada masyarakat. Deposito biasanya memiliki jangka waktu tertentu, di mana uang di dalamnya tidak boleh ditarik nasabah. Bunga deposito biasanya lebih tinggi daripada bunga tabungan biasa. Setiap tahun posisi deposito selalu mendominasi penghimpunan dana pihak ketiga. Salah satu faktor penting yang mempengaruhi penghimpunan dana pihak ketiga adalah suku bunga SBI. Dimana semakin tinggi suku bunga SBI, semakin besar pula dana yang dihimpun oleh bank dari masyarakat. Hal ini disebabkan karena kenaikan suku bunga SBI akan mempengaruhi suku bunga pada bank umum. Jjika suku bunga bank umum meningkat, maka masyarakat akan lebih tertarik menyimpan uangnya di bank.

Hasil penelitian ini juga sesuai dengan penelitian yang telah dilakukan oleh Sopiana (2012) menunjukkan bahwa ada pengaruh antara suku bunga SBI dan inflasi terhadap dana pihak ketiga perbankan di Indonesia pada tahun 1984 hingga 2010. Selanjutnya penelitian ini juga sesuai dengan penelitian yang telah dilakukan oleh Nurfaizah dan Parmitasari (2015) menunjukkan bahwa terdapat hubungan yang positif dan signifikan antara tingkat suku bunga dengan jumlah dana deposito pada Bank Mandiri Cabang Makassar.

\section{KESIMPULAN DAN SARAN}

\section{Kesimpulan}

Berdasarkan hasil penelitian, dapat ditarik kesimpulan bahwa tingkat suku bunga deposito berpengaruh terhadap dana pihak ketiga di Bank BJB Cabang Rangkasbitung.

\section{Saran}


Adapun saran-saran yang diberikan dalam penelitian ini adalah: 1). Industri Perbankan dipengaruhi oleh jumlah dana nasabah yang disimpan. Oleh karena itu perbankan disarankan untuk memberikan bunga kompetitif kepada para deposan. Sehingga akan meningkatkan dana pihak ketiga yang disimpan di bank. 2). Selain itu juga perbankan harus memberikan bunga yang kompetitif spada produk dana pihak ketiga lain seperti tabungan dan giro, sehingga nasabah memiliki banyak pilihan produk. 3). Para nasabah harus memperhitungkan jumlah bunga yang diterima dari deposito yang diinvestasikan. Agar bunga yang diterima lebih tinggi dari tingkat inflasi yang terjadi.

\section{DAFTAR PUSTAKA}

Abdurahman, Maman, et al. 2011. Dasar-dasar Metode Statistika untuk Penelitian. Bandung: CV Pustaka Setia

Ajija, Shocrul R, et al. 2019. Cara Cerdas Menguasai E-Views. Jakarta: Salemba Empat

Boediono. 2014. Seri Sinopsis Pengantar Ilmu Ekonomi No. 5 Ekonomi Makro. Yogyakarta: BPFE.

Husein, Umar. 2014. Metode Penelitian untuk Skripsi dan Tesis Bisnis. Jakarta: PT. Raja Grafindo Persada

Ismail. 2010. Manajemen Perbankan. Edisi Pertama. Jakarta: Kencana

Kasmir. 2010. Bank dan Lembaga Keuangan Lainnya. Edisi Revisi 2008. Jakarta: PT. Raja Grafindo Persada.
Mishkin, Frederic S. 2008. Ekonomi Uang, Perbankan, dan Pasar Keuangan. Edisi8. Jakarta: Salemba Empat.

Nurfaizah dan Parmitasari. 2015. Pengaruh Tingkat Suku Bunga Deposito Terhadap Jumlah Dana Deposito Pada Bank Mandiri Cabang Utama Makassar. Jurnal Iqtisaduna Vol. 1, No. 2 PISSN:2460-805X, E-ISSN: 25500295.

Riduwan dan Kuncoro, Engkos Achmad. 2014. Cara Menggunakan dan Memakai Path Analysis (Analisis Jalur). Bandung: CV. Alfabeta

Sawaldjo Puspopranoto. 2004. Keuangan Perbankan dan Pasar Keuangan. Jakarta: Pustaka LP3ES Indonesia.

Sopiana, Herli. 2012. Analisis pengaruh suku bunga SBI dan inflasi terhadap penghimpunan Dana Pihak Ketiga (DPK) Perbankan di Indonesia. Jurnal Ekonomi Pembangunan, Vol. 10, No.1, Juni 2012. Hal. 12-30.

Sugiyono. 2006. Metode Penelitian Kuantitatif, Kualitatif dan $R \& D$. Bandung: CV. Alfabeta.

Sunariyah. 2013. Pengantar Pengetahuan Pasar Modal. Edisi 6. Yogyakarta: UPP STIM YKPN.

Wahyudi, Setyo Tri. 2016. Kosep dan Penerapan Ekonometrika Menggunakan E-Eviews. Jakarta: PT. Raja Grafindo Persada.

Yusuf, Muri. 2016. Metode Penelitian Kuantitatif, Kualitatif \& Penelitian Gabungan. Jakarta: Prenadamedia Group. 